\title{
Characterisation of the mural paintings from the Misericordia Church of Odemira (Portugal)
}

Sara Valadas ${ }^{1}$, Deolinda Tavares ${ }^{2}$, João Coroado ${ }^{3}$, António S. Silva ${ }^{4}$, Jorge Pedro ${ }^{5}$, José Mirão ${ }^{5}$ \& António Candeias ${ }^{1, a}$

${ }^{1}$ Chemistry Department and Evora Chemistry Center, University of Évora,

R. Romão Ramalho, 59, 7000-676 Évora, Portugal

${ }^{2}$ Instituto Português do Património Arquitectónico, Regional Service of Évora,

R. Burgos, 5, 7000 - 863 Évora, Portugal

${ }^{3}$ Art, Conservation and Restoration Department, Polytechnic Institute of Tomar, Quinta do Contador, 2300-313 Tomar, Portugal

${ }^{4}$ Materials Department, Laboratorio Nacional de Engenharia Civil, Av. Brasil 101, 1700-066 Lisbon, Portugal

${ }^{5}$ Geosciences Department and Evora Geophysics Center, University of Évora, R. Romão Ramalho, 7000-676 Évora, Portugal

acCorresponding author: candeias@uevora.pt

Keywords: Mural paintings, Mortars, Pigments, Characterization

\begin{abstract}
Several mortars from mural paintings were collected from the Misericórdia Church of Odemira and analysed by using different techniques namely X-ray diffraction, thermogravimetric analysis with differential thermal analysis, SEM-EDX, optical microscopy, CHNS elemental analysis and chemical analysis. Microfragments of paint layers were collected and analysed by microchemical analysis. The results showed that the mortars are aerial lime mortars with siliceous aggregates and that the pigments used were from local sources.
\end{abstract}

Full article : doi:10.4028/0-87849-373-5.1019 